\title{
Molecular analyses of microbial abundance and diversity in the water column of anchialine caves in Mallorca, Spain
}

\author{
Damian M. Menning ${ }^{1}$, Liana M. Boop ${ }^{2}$, Elaina D. Graham ${ }^{1}$, and James R. Garey ${ }^{1 *}$ \\ ${ }^{1}$ Department of Cell Biology, Microbiology, and Molecular Biology, University of South Florida, 4202 E. Fowler Ave., ISA 2015, Tampa, FL, 33620 \\ ${ }^{2}$ School of Geosciences, University of South Florida, 4202 E. Fowler Ave., NES 107, Tampa, FL, 33620
}

\begin{abstract}
Water column samples from the island of Mallorca, Spain were collected from one site in Cova des Pas de Vallgornera (Vallgornera) and three sites (Llac Martel, Llac Negre, and Llac de les Delícies) in Coves del Drac (Drac). Vallgornera is located on the southern coast of Mallorca approximately $57 \mathrm{~km}$ southwest of Coves del Drac. Drac is Europe's most visited tourist cave, whereas Vallgornera is closed to the public. Water samples were analyzed for water chemistry using spectrophotometric methods, by quantitative PCR for estimated total abundance of microbial communities, and by length heterogeneity PCR for species richness and relative species abundance of Archaea, Bacteria, and microbial eukaryotes. Estimated total abundance was multiplied by relative species abundance to determine the absolute species abundance. All sites were compared to determine spatial distributions of the microbial communities and to determine water column physical and chemical gradients. Water quality and community structure data indicate that both Drac Delícies and Drac Negre have distinct biogeochemical gradients. These sites have communities that are similar to Vallgornera but distinct from Drac Martel, only a few hundred meters away. Drac Martel is accessible to the general public and had the most dissimilar microbial community of all the sites. Similarities among communities at sites in Drac and Vallgornera suggest that these two spatially separated systems are operating under similar ecological constraints.
\end{abstract}

Keywords: $\quad$ water quality; estimated total abundance; species richness; relative species abundance; microbial; community structure; anchialine; Mallorca

Received 8 October 2013; Revised 28 May 2014; Accepted 1 June 2014

Citation: $\quad$ Menning D.M., Boop L.M., Graham E.D. and Garey J.R. 2014. Molecular analyses of microbial abundance and diversity in the water column of anchialine caves in Mallorca, Spain. International Journal of Speleology, 43 (2), 217-226. Tampa, FL (USA) ISSN 0392-6672 http://dx.doi.org/10.5038/1827-806X.43.2.9

\section{INTRODUCTION}

Biological communities, especially microbial communities, are important because they help shape the geochemistry within cave systems (Lovley \& Chapelle, 1995; Léveillé et al., 2007; Por, 2007). These communities may contribute to speleothem formation as seen by Curry et al. (2009) who found calcitic deposits in Cataract Cave, Alaska, that were intertwined with microbial filaments they considered as biologically-influenced organominerals. These communities can also act as biological tracers in the same manner as stable isotopes to show hydrologic connections between systems (Ward \& Palmer, 1994; Sanchez et al., 2002). Venarsky et al. (2009) found that the genetic structure of aquatic invertebrate populations within cave systems can be used to identify and prioritize geographic regions for conservation. Differences between microbial communities at different depths can be used to indicate the presence of geochemical gradients in the water column that help characterize the stability and potential mixing of waters within individual cave systems (Gili et al., 1986; Torres-Talamante et al., 2011).

Molecular techniques such as DNA sequencing, length heterogeneity PCR (LH-PCR), and quantitative PCR (q-PCR) (Suzuki et al., 1998; Ginzinger, 2002; Sogin et al., 2006; Ducklow et al., 2011) have provided the means to estimate biological species richness and abundance in cave systems (Garman et al., 2011; Garey \& Menning, 2012). Length heterogeneity PCR uses fluorescently labeled primers targeted to conserved regions that flank highly variable regions of genes such as the 16S rRNA gene. Different fragment lengths, as determined by gel electrophoresis, represent the 16S rRNA genes of different organisms. These data are used to estimate the relative abundance of species and species richness within a site and identify species that are present across sites. The method is fast, reproducible, and cost-effective, 
but does not provide as precise identification as DNA sequence analysis allows. Quantitative PCR can be used to estimate the amount of DNA in a sample using primers targeted to conserved regions of rRNA genes. These data can be used to estimate increases and/or decreases in the absolute size of a community (Lloyd et al., 2013). Length heterogeneity PCR and q-PCR, when combined, can provide an estimate of absolute species abundance in a sample. These techniques can be used to determine similarities and differences between communities at different depths in the water column of each site, between sites within an individual cave, and between cave systems.

The purposes of this study are to: (1) describe the physical and chemical gradients that occur in the water columns of two cave systems on the Island of Mallorca; (2) determine if microbial communities within these caves vary with the physical and chemical water gradients; and (3) characterize the differences in microbial communities with different levels of spatial separation.

\section{METHODS}

\section{Site description}

Mallorca is the largest island in the Balearic Islands archipelago located off the eastern coast of Spain in the Mediterranean Sea. The coastal area of the island is approximately 45\% karst limestone (Balaguer, 2005). Coves del Drac (Drac) is located on the eastern coast of the island under the town of Porto Cristo and contains three main galleries ending with brackish pools, Llac Martel, Llac Negre and Llac de les Delícies (hereafter Drac Martel, Drac Negre, and Drac Delicies). Cova des Pas de Vallgornera (Vallgornera) is located $57 \mathrm{~km}$ to the southwest of Drac on the southern coast under the town of Cala Pi (Fig. 1). Within Drac, the Llac Martel site is along a tourist route (Robledo \& Duran, 2010), whereas the Llac Negre and Llac de les Delicies sites are not open to the public (Fig. 2). Vallgornera is not accessible to the general public. Both cave systems are anchialine, found in Upper Miocene rock, and are located in the subterranean mixing zone comprised of fresh groundwater and

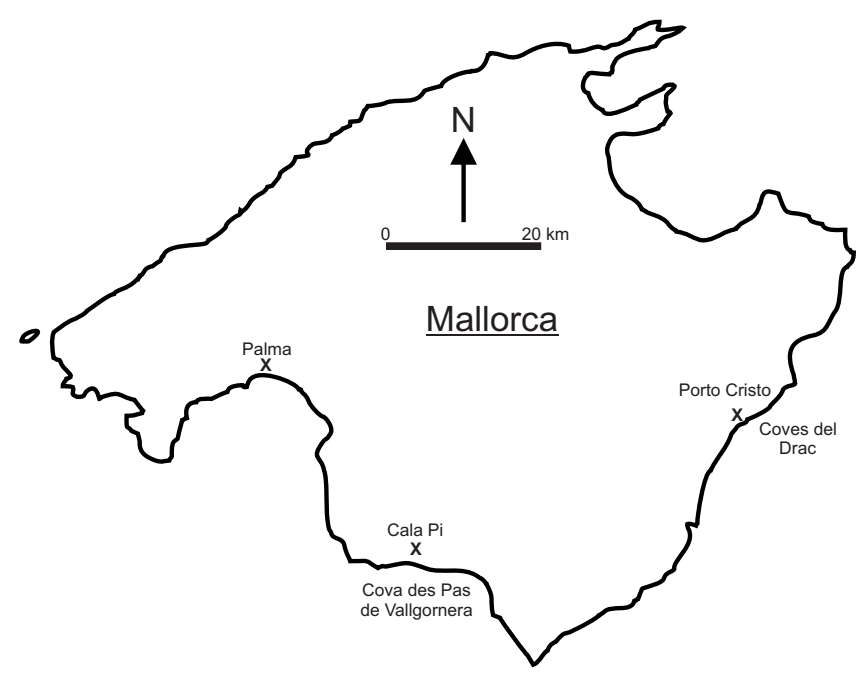

Fig. 1. Locations of Cova des Pas de Vallgornera and Coves del Drac in Mallorca, Spain.

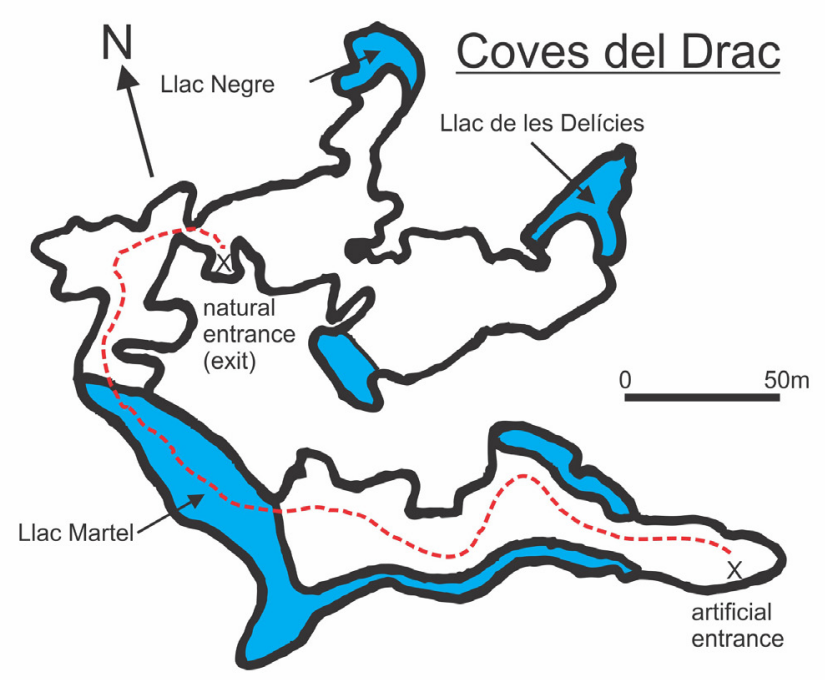

Fig. 2. Map of Coves del Drac showing sample sites. Solid black lines designate the cave boundaries, blue regions depict underground lakes and pools. Dotted lines show the tourist pathways (after Ginés \& Ginés, 2007).

marine water from the Mediterranean Sea. These caves have submerged and dry passages (Ginés et al., 2012). Samples were collected from the brackish water bodies within each cave.

\section{Sampling}

Water column samples were collected from a single site in Vallgornera and from the three sites in Drac (Figs. 1 \& 2) in March 2013. Four replicates of 500 $\mathrm{ml}$ were collected at each location from three depths (the surface, $1 \mathrm{~m}$, and $2 \mathrm{~m}$ ) using a 1077 Model JT-1 Water Sampler (LaMotte, USA). All samples were kept at $4^{\circ} \mathrm{C}$ until further processing. Concurrent with water column sampling, a HI 9828 Multiparameter Meter (Hanna Instruments, USA) was used to measure water temperature, dissolved oxygen, oxidation reduction potential (ORP), $\mathrm{pH}$, salinity, and total dissolved solutes.

\section{Sample processing}

All water column samples were filtered through $47 \mathrm{~mm}$ diameter $0.2 \mu \mathrm{m}$ pore size filters (Millipore, USA). The filtered water was used for subsequent chemical analyses. The $47 \mathrm{~mm}$ filters were stored at $-20^{\circ} \mathrm{C}$ until further processing. Microorganisms were extracted from the filters by scraping the filter with a sterile DNA-free spatula in $1.5 \mathrm{ml}$ of $\mathrm{pH} 7$ phosphate buffered saline, followed by 30 seconds of vortexing in a $15 \mathrm{ml}$ conical tube. The filters were washed twice in this manner. DNA extractions were performed using an Ultraclean Fecal DNA Kit (MoBIO, USA) following the manufacturer's protocols except that following the bead beating step the supernatant was split into two $400 \mu 1$ aliquots and processed in parallel. The aliquots were recombined during the first spin filter step. DNA concentrations were determined using a Thermo Scientific Nanodrop 2000 Spectrophotometer (Fisher Scientific, USA).

\section{Water chemistry}

Due to logistical constraints, only one water sample from each site and depth was analyzed for chemical parameters. Nitrate, ammonia, sulfate, hardness, and 
phosphate concentrations were determined for each sample using a DR/2400 Portable Spectrophotometer (HACH, USA). Total alkalinity was measured with an Orion Total Alkalinity Test Kit (Thermo Fisher Scientific, USA).

\section{Quantitative PCR}

Quantitative PCR was conducted on all samples to estimate the total abundance of Archaea, Bacteria (Olliver et al., 2014), and microbial eukaryotes in the water column using a Realplex ${ }^{2}$ Mastercycler (Eppendorf, USA). Fluorescent molecules are included in the PCR reaction mix to allow the quantification of amplified DNA fragments in real time. This allows the estimation of the quantity of original template DNA. The 16S (Giovannoni, 1991; Lane, 1991; Reysenbach \& Pace, 1995; Baker et al., 2003) and 18S (Sogin \& Gunderson, 1987) rRNA gene primers used for each domain are listed in Table 1. Each reaction was performed in a $20 \mu \mathrm{L}$ volume containing $2 \mu \mathrm{L}$ of sample DNA, $0.5 \mu \mathrm{L}$ of each primer $(10 \mathrm{mM}), 10 \mu \mathrm{L}$ of SYBR Premix Ex Taq II (Takara, USA), and $7 \mu \mathrm{L}$ of nanopure water. The $\mathrm{q}-\mathrm{PCR}$ reaction conditions were: initial denaturation at $95^{\circ} \mathrm{C}$ for 30 seconds followed by 40 cycles of denaturing for 10 seconds at $95^{\circ} \mathrm{C}$, annealing for 20 seconds (see Table 1 for temperature used for each primer set), and extension for 45 seconds at $70^{\circ} \mathrm{C}$. A positive control (DNA from pure microbial culture, see Table 1) and a negative control (no DNA) were run to verify PCR efficiency. Log-linear standard curves were made using five 1:10 serial dilutions of DNA of known concentration from control organisms from full concentration to 10-5 dilution (Table 1). Estimated total microbial abundance provided in this study was determined by comparing the cycle threshold $(\mathrm{Ct})$ values generated from the samples to a standard curve created at the same time from a pure culture of a known organism with a known DNA concentration and extrapolating the estimated total abundance from the standard curve.

\section{Length heterogeneity PCR}

Length heterogeneity PCR is a molecular technique used to compare biological communities by determining the lengths of fragments generated from each microbial species in the samples. PCR primers were selected that amplify variable regions of the target $16 \mathrm{~S}$ and $18 \mathrm{~S}$ rRNA genes. Each fragment size is assumed to represent a unique species, both within a sample and across samples. This allows a rapid estimation of the microbial communities and the comparison of communities across sites. LHPCR does not identify particular species and tends to underestimate species richness and overestimate relative species abundance (Marzorati et al. 2008). LH-PCR was conducted using an ABI 3130 4-capillary Genetic Analyzer (Applied Biosystems, USA). Ten ng of DNA were used as the template for each reaction. The 16S and 18S rRNA gene primers used for each domain are listed in Table 1 . The forward primer of each set was labeled with a 56-FAM fluorescent tag. A positive control (DNA from a pure microbial culture, see Table 1) and negative control (no DNA) were run to verify PCR efficiency. Length heterogeneity PCR mixtures consisted of a $50 \mu \mathrm{L}$ volume composed of 5 $\mu 1$ of 10X PCR Reaction Buffer (IDLabs, Canada), $1 \mu 1$ of each primer solution (10 mM), $1 \mu \mathrm{dNTP}$ solution (10 mM), $0.25 \mu \mathrm{L}$ Idproof DNA Polymerase (1.25 U) (IDLabs, Canada), $10 \mathrm{ng}$ of DNA (volume varies with sample), and nanopure water to $50 \mu \mathrm{L}$. A T3 Thermocycler (Biometra, Germany) was programed for an initial denaturation of 120 seconds at $95^{\circ} \mathrm{C}$ followed by 30 cycles of denaturation for 30 seconds at $95^{\circ} \mathrm{C}$, annealing for 30 seconds (see Table 1 for temperature used for each primer set), and extension for 60 seconds at $72^{\circ} \mathrm{C}$. A final extension was carried out for seven minutes at $72^{\circ} \mathrm{C}$. PCR products $(0.5 \mu \mathrm{L})$ were denatured in $9.0 \mu \mathrm{Hi}$-Di formamide (Applied Biosystems, USA) with $0.5 \mu \mathrm{L}$ GeneScan 600 LIZ internal size standard (Applied Biosystems, USA). Sample mixtures were heated for five minutes at $95^{\circ} \mathrm{C}$, immediately placed in an ice bath for five minutes, and loaded on the genetic analyzer. Electropherograms were analyzed using Gene Mapper v4.0 (Applied Biosystems, USA). The expected amplicons contain two conserved flanking regions and two internal variable regions. Peaks from fragments of a size representing only the conserved flanking regions or less (250 bp for Archaea, $300 \mathrm{bp}$ for Bacteria and microbial eukaryotes) were omitted from further analysis in order to only use fragments containing variable regions which represent unique species (Suzuki et al., 1998). Species richness was determined by counting the total number of peaks from each electropherogram. Relative species abundance of each peak was determined by dividing each individual peak area by the total area of all peaks in the sample used in the analysis to determine the proportion of each species in the sample.

Table 1. List of primers used for LH-PCR and q-PCR with associated data.

\begin{tabular}{|c|c|c|c|c|c|}
\hline Primer & Sequence $\left(5^{\prime}-3^{\prime}\right)$ & $\underline{\text { Regions Covered }}$ & $\frac{\text { Annealing }}{\text { temp. }\left({ }^{\circ} \mathrm{C}\right)}$ & Positive Control & $\frac{\text { Undiluted Concentration of }}{\underline{\text { Control Organism DNA }}}$ \\
\hline \multicolumn{6}{|l|}{ Archaea } \\
\hline A1098F & CNGGCAACGAGCGMGACCC & $7-8$ & $50^{\circ} \mathrm{C}$ & Sulfolobus solfataricus & $278.8 \mathrm{ng} / \mu \mathrm{L}$ \\
\hline UA1406R & AACRTGWGTGGCGGGCA & & & & \\
\hline \multicolumn{6}{|l|}{ Bacteria } \\
\hline $27 \mathrm{~F}$ & AGAGTTTGATCCTGGCTCAG & $1-2$ & $50^{\circ} \mathrm{C}$ & Escherichia coli & $299.6 \mathrm{ng} / \mu \mathrm{L}$ \\
\hline $355 \mathrm{R}$ & GCTGCCTCCCGTAGGAGT & & & & \\
\hline \multicolumn{6}{|l|}{ Eukaryote } \\
\hline $1961 \mathrm{~F}$ & TGGTGCATGGCCGTTCTTAG & $5-6$ & $55^{\circ} \mathrm{C}$ & Caenorhabditis elegans & $81.1 \mathrm{ng} / \mu \mathrm{L}$ \\
\hline $2532 R$ & CGGTGTGTACAAAGGGCAGGG & & & & \\
\hline
\end{tabular}




\section{Statistical analysis}

Relative species abundance (LH-PCR) data was multiplied by estimated total abundance (q-PCR) data to calculate estimated absolute abundance. This dataset was analyzed by non-parametric multivariate analysis of multidimensional scaling (MDS) based on Bray-Curtis similarity using Primer v6 statistical software (Primer-E Ltd, UK). Least significant difference post-hoc tests were conducted on all estimated total abundance and species richness data to determine statistically significant differences $(p<0.05)$ between samples at different depths at each site and between all sites using SPSS 20.0 (IBM, USA).

\section{RESULTS AND DISCUSSION}

Physical and chemical parameters sampled at all sites and depths are shown in Figure 3. Temperature, salinity, total dissolved solids, dissolved oxygen, hardness, ORP, and sulfate generally increase at all locations with increasing depth with a few exceptions. In contrast, two studies of anchialine water bodies in the caves of Mallorca (Carey et al., 2001; Sintes et al., 2004) found dissolved oxygen decreased with depth. Both of these studies also found that temperature and salinity increased with depth. The increases of salinity, dissolved oxygen, total dissolved solutes, sulfate, and temperature with depth observed in our study suggests that these caves have relatively warm oxygenated water entering the systems from below, presumably via salt water from the Mediterranean Sea.

Alkalinity, $\mathrm{pH}$, and phosphate appeared to decrease at all locations with depth in our study. Zic et al. (2011) found similar patterns in anchialine caves in Croatia where phosphate and alkalinity decreased with depth, while $\mathrm{pH}$ decreased with depth to 4-6 m then increased. In our study, nitrate and ammonia did not appear to change with depth in a consistent pattern, similar to Zic et al. (2011) who found that nitrate did not change with depth in January 2010 but decreased with depth in January and July of 2009. They also found that ammonium did not change with depth in January 2010 but oscillated with depth in January and July of 2009.

The chemical gradients seen in the caves in this study can be explained by overlying fresh water mixing with deeper Mediterranean-derived salt water. Carey et al. (2001) found that in some of the water bodies of the caves of Mallorca, the amount of freshwater changes with the amount of rainfall entering the caves. They

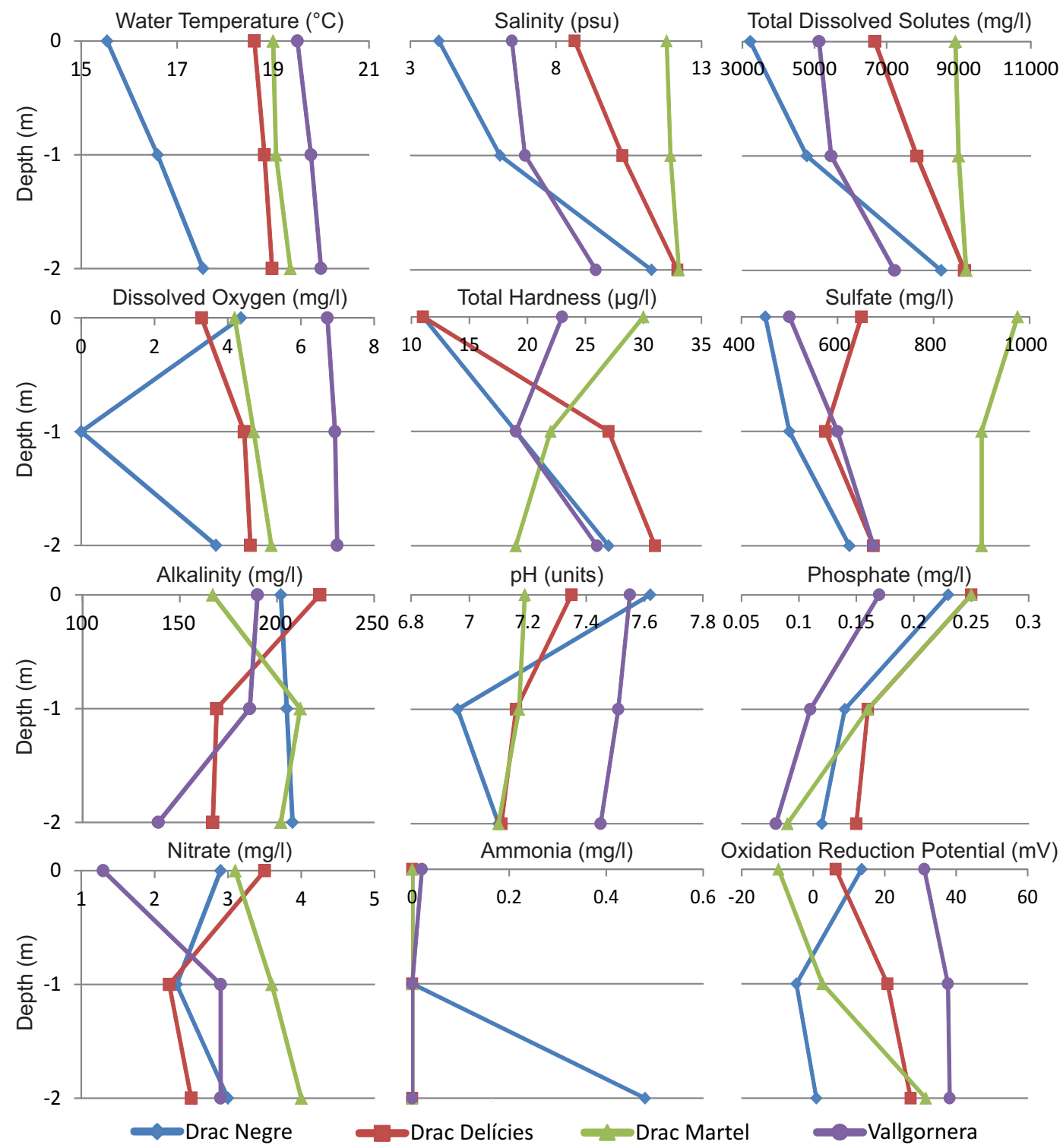

Fig. 3. Physical and chemical water profiles showing differences between sites by depth. Water temperature and salinity from Boop et al. (2014). 
did not find a clear halocline in Cala Varques ' $\mathrm{A}$ ', which they attributed to brackish water entering the cave or possibly turbulent mixing of the overlying freshwater with the underlying saltwater but did find a halocline in Cova de na Barxa. They concluded that all the water bodies they studied showed similar chemical and physical profiles with increases of salinity and temperature and decreases of dissolved oxygen with depth. Some chemical constituents at the different sites in our study did not consistently follow the salt gradient as seen in Carey et al. (2001). Drac Negre had the lowest temperature compared to the other sites with a surface temperature $3-4^{\circ} \mathrm{C}$ below the other sites and $2^{\circ} \mathrm{C}$ lower at a depth of $2 \mathrm{~m}$. It also appeared to be an outlier in terms of salinity, total dissolved solutes, dissolved oxygen, sulfate, ammonia, and ORP at one or more depths compared to the other sites (Fig. 3). This suggests that the water at Drac Negre has different inputs from that of the other sites. One possibility is that the Drac Negre site could be more strongly influenced by groundwater than the other sites which could explain the drop in dissolved oxygen content at the $1 \mathrm{~m}$ sample. The Drac Martel site appears to have the weakest salinity gradient from the surface to $2 \mathrm{~m}$, suggesting that the water column is more mixed than the other sites. This could be due to the boat traffic transporting tourists across the water at Drac Martel (Fig. 2).

\section{Total abundance estimated by q-PCR}

Estimated total abundance of microbes as determined by q-PCR is shown in Table 2. Archaea appear to have the highest concentration of DNA per liter at all sites representing $94.4-97 \%$ of each sample followed by bacterial DNA (3.0-5.6\%) and microbial eukaryote DNA (0.0-1.1\%). These differences could be due to the different PCR primer sets used for each domain (e.g. Archaea, Bacteria, Eukaryota) and primer efficiency could vary with different primer sets specific for the different domains (Lloyd et al., 2013). In a study of a hypersaline lake in Turkey, Mutlu et al. (2008) found similar results where Archaea also appeared to be the most prevalent component of the microbial community. In this study, comparisons of estimated total abundance between all sites and depths show that microbial eukaryotes had the highest differences (235 fold). The absolute amounts of eukaryote DNA were so low that generally there were no significant differences among depths at each site. The eukaryote estimated total abundance was significantly higher in Drac Negre than the other three sites, including Vallgornera. Estimated total abundance of Bacteria varied 17 fold and Archaea eight fold. Vallgornera and Drac Negre showed an increase of estimated total prokaryote abundance with depth, whereas Drac Delícies showed a decrease with depth. In Drac Martel, estimated prokaryote abundance decreased from the surface to $1 \mathrm{~m}$ and then increased at a depth of $2 \mathrm{~m}$. Archaea appear to be the most prevalent component of the water column community within the sampled caves.

Least significant difference post-hoc tests of estimated total abundance between all sites are shown in Table 3 . These data indicate that all of the prokaryote communities are significantly different from each other with an exception found between Drac Martel and Vallgornera. Conversely, the only differences observed between prokaryote communities were seen between Drac Negre and the other 3 sites. This suggests that the different parts of the Drac system may have become distinct niches with potentially unique communities. Culver (1970) found that three gammarid amphipods inhabiting cave streams separated into niches based on habitat conditions such as stream flow and substrate. While amphipods were not examined in our study, Culver's study shows that biological communities can separate into distinct ecological niches within the same cave system as we found with the microbial communities. The estimated total abundance of Drac Martel was not significantly different from Vallgornera indicating that both systems may be operating under similar ecological constraints. Microbial eukaryotes in Drac Negre appeared to be significantly higher in abundance than the three other sites indicating a separate niche environment within Drac Negre.

Table 2. Estimated total abundance (average amount of DNA) as determined by q-PCR.

\begin{tabular}{|c|c|c|c|c|c|c|c|c|}
\hline Archaea & \multicolumn{2}{|c|}{ Vallgornera } & \multicolumn{2}{|c|}{ Drac Negre } & \multicolumn{2}{|c|}{ Drac Delícies } & \multicolumn{2}{|c|}{ Drac Martel } \\
\hline Depth (m) & Ave DNA (ng/L) & Std Dev & Ave DNA (ng/L) & Std Dev & Ave DNA (ng/L) & Std Dev & Ave DNA (ng/L) & Std Dev \\
\hline 0 & 175.78 & 42.78 & 396.62 & 224.72 & 1403.55 & 222.78 & 429.56 & 71.41 \\
\hline-1 & 387.31 & 190.76 & 1769.48 & 1045.37 & 787.06 & 149.46 & 223.27 & 127.76 \\
\hline-2 & 478.77 & 241.17 & 1753.42 & 712.63 & 283.67 & 151.98 & 421.82 & 179.29 \\
\hline Bacteria & \multicolumn{2}{|c|}{ Vallgornera } & \multicolumn{2}{|c|}{ Drac Negre } & \multicolumn{2}{|c|}{ Drac Delícies } & \multicolumn{2}{|c|}{ Drac Martel } \\
\hline Depth (m) & Ave DNA (ng/L) & Std Dev & Ave DNA (ng/L) & Std Dev & Ave DNA (ng/L) & Std Dev & Ave DNA (ng/L) & Std Dev \\
\hline 0 & 6.07 & 1.95 & 15.44 & 8.63 & 82.82 & 12.39 & 15.05 & 3.71 \\
\hline-1 & 14.57 & 8.25 & 93.23 & 50.75 & 36.52 & 6.66 & 7.38 & 4.71 \\
\hline-2 & 19.15 & 10.91 & 103.28 & 36.10 & 11.06 & 6.37 & 13.05 & 8.45 \\
\hline Eukaryote & \multicolumn{2}{|c|}{ Vallgornera } & \multicolumn{2}{|c|}{ Drac Negre } & \multicolumn{2}{|c|}{ Drac Delícies } & \multicolumn{2}{|c|}{ Drac Martel } \\
\hline Depth (m) & Ave DNA (ng/L) & Std Dev & Ave DNA (ng/L) & Std Dev & Ave DNA (ng/L) & Std Dev & Ave DNA (ng/L) & Std Dev \\
\hline 0 & 0.17 & 0.16 & 4.70 & 3.21 & 0.22 & 0.15 & 0.03 & 0.03 \\
\hline-1 & 0.05 & 0.03 & 2.98 & 5.22 & 0.14 & 0.09 & 0.02 & 0.01 \\
\hline-2 & 0.11 & 0.14 & 0.55 & 0.54 & 0.05 & 0.04 & 0.04 & 0.03 \\
\hline
\end{tabular}


Table 3. Least Significant Difference Post-Hoc showing statistically significant differences of estimated total abundance and species richness between sites.

\begin{tabular}{|c|c|c|c|c|}
\hline \multirow{2}{*}{\multicolumn{2}{|c|}{$\begin{array}{l}\text { Estimated total abundance } \\
\text { Dependent variable (cave) }\end{array}$}} & \multicolumn{3}{|c|}{ Significance } \\
\hline & & \multirow{2}{*}{$\frac{\text { Archaea }}{0.000}$} & \multirow{2}{*}{$\frac{\text { Bacteria }}{0.000}$} & \multirow{2}{*}{$\frac{\text { microbial eukaryotes }}{0.001}$} \\
\hline Vallgornera & Drac Negre & & & \\
\hline Vallgornera & Drac Delícies & 0.016 & 0.007 & \\
\hline Vallgornera & Drac Martel & & & \\
\hline Drac Martel & Drac Negre & 0.000 & 0.000 & 0.001 \\
\hline Drac Martel & Drac Delícies & 0.026 & 0.008 & \\
\hline Drac Negre & Drac Delícies & 0.020 & 0.019 & 0.001 \\
\hline \multicolumn{2}{|c|}{ Species richness } & \multicolumn{3}{|c|}{ Significance } \\
\hline \multicolumn{2}{|c|}{ Dependent variable (cave) } & Archaea & Bacteria & microbial eukaryotes \\
\hline Vallgornera & Drac Negre & 0.000 & & \\
\hline Vallgornera & Drac Delícies & & 0.000 & \\
\hline Vallgornera & Drac Martel & & & \\
\hline Drac Martel & Drac Negre & 0.000 & & \\
\hline Drac Martel & Drac Delícies & & 0.000 & \\
\hline Drac Negre & Drac Delícies & 0.000 & 0.000 & 0.042 \\
\hline
\end{tabular}

Least significant difference post-hoc tests of estimated total abundance by depth at each site (Table 4) show that Drac Martel did not have any significant differences between depths in estimated total abundance for any domain whereas Drac Delícies showed statistically significant differences of Archaea and Bacteria abundances between all depths and statistically significant differences of microbial eukaryote abundance from the surface to $2 \mathrm{~m}$. It appears from both salinity measurements and estimated total abundance that the water column in Drac Martel is well mixed, probably due to boat traffic while Drac Delícies is relatively undisturbed allowing biological gradients to form. Vallgornera and Drac Negre both showed statistically significant differences in Archaea and Bacteria abundance between the surface and $2 \mathrm{~m}$ but no differences between $1 \mathrm{~m}$ and $2 \mathrm{~m}$. Drac Delicies was the only site that showed significant differences among depths for estimated total abundance of microbial eukaryotes. These data indicate that Drac Negre and Vallgornera have biological gradients that are less developed than Drac Delicies but more developed than Drac Martel. In a study of cavernicolous ciliates from anchialine water bodies in Mallorca, Carey et al. (2001) found that the populations were clearly stratified within them. Although ciliates were not specifically measured in our study, the universal eukaryotic primers we used for community structure analyses would include these organisms.

\section{Species richness estimated by LH-PCR}

Average species richness among all sites as estimated by LH-PCR is shown in Table 5. Archaea had the highest species richness across all sites with an average of 16 to 30.4 peaks per sample, followed by Bacteria (average of 1.0 to 25.2 peaks per sample), and microbial eukaryotes (average of 2.4 to 5.2 peaks per sample). Species richness either decreased or did not change with depth in Vallgornera, Drac Delicies, and Drac Martel, but increased with depth in Drac Negre. In a study of microbial communities inhabiting an anchialine sinkhole in Australia, Seymour et al. (2007) found that abundances of different groups of phytoplankton, Bacteria, and viruses varied with depth although concentrations were generally highest from the surface to $1 \mathrm{~m}$. In our study, Drac Delicies was an exception where the number of bacterial peaks was much lower than the other sites although the number of archaeal and microbial eukaryote peaks were similar to those of the other sites. Considering that the amount of bacterial DNA from Drac Delicies samples was similar to other sites, but significantly lower in number of LH-PCR peaks, it appears that for some unknown reason, bacterial biodiversity at Drac Delícies is considerably less than the other sites.

Least significant post-hoc tests of species richness between sites (Table 3) indicate that Drac Negre had significantly different species richness of Archaea from that of the other three sites while Drac Delicies had significantly different species richness of Bacteria. The species richness of microbial eukaryotes was significantly different only between Drac Delícies and Drac Negre. Similar analyses of species richness by depth (Table 4) showed statistically significant differences of Archaea at Vallgornera and Drac Martel and of Bacteria at Drac Negre and Drac Delicies but no statistically significant differences were seen between microbial eukaryotes at any site. The unique archaeal communities in Drac Negre and the unique bacterial communities in Drac Delícies indicate a separation of biological communities into distinct niche habitats as was seen with gammarid amphipods in the study by Culver (1970).

\section{Species richness and abundance}

Estimated total abundance analyses suggests that the archaeal communities are similar (species richness) at different depths but different in amount (estimated total abundance) within Drac Negre and Drac Delicies. These analyses also indicate that the species richness of bacterial communities at Drac Negre and Drac Delícies vary with depth in the same

Table 4. Least Significant Difference Post-Hoc showing statistically significant differences of estimated total abundance and species richness at each site between depths.

\begin{tabular}{|c|c|c|c|c|c|c|}
\hline \multicolumn{3}{|c|}{ Estimated total abundance } & \multicolumn{4}{|c|}{ Significance } \\
\hline Dependent variable & \multicolumn{2}{|c|}{$\begin{array}{l}\text { Depth } \\
(\mathrm{m})\end{array}$} & Vallgornera & $\begin{array}{c}\text { Drac } \\
\text { Negre }\end{array}$ & $\begin{array}{c}\text { Drac } \\
\text { Delícies }\end{array}$ & $\begin{array}{c}\text { Drac } \\
\text { Martel }\end{array}$ \\
\hline \multirow[t]{3}{*}{ Archaea } & 0 & -1 & & 0.023 & 0.000 & \\
\hline & 0 & -2 & 0.020 & 0.024 & 0.000 & \\
\hline & -1 & -2 & & & 0.002 & \\
\hline \multirow[t]{3}{*}{ Bacteria } & 0 & -1 & & 0.011 & 0.000 & \\
\hline & 0 & -2 & 0.024 & 0.005 & 0.000 & \\
\hline & -1 & -2 & & & 0.002 & \\
\hline microbial eukaryotes & 0 & -2 & & & 0.042 & \\
\hline Species richness & & & \multicolumn{4}{|c|}{ Significance } \\
\hline Dependent variable & \multicolumn{2}{|c|}{$\begin{array}{l}\text { Depth } \\
(\mathrm{m})\end{array}$} & Vallgornera & $\begin{array}{c}\text { Drac } \\
\text { Negre }\end{array}$ & $\begin{array}{c}\text { Drac } \\
\text { Delícies }\end{array}$ & $\begin{array}{c}\text { Drac } \\
\text { Martel }\end{array}$ \\
\hline Archaea & 0 & -2 & 0.050 & & & 0.009 \\
\hline \multirow[t]{3}{*}{ Bacteria } & 0 & -1 & & 0.000 & & \\
\hline & 0 & -2 & & 0.000 & 0.005 & \\
\hline & -1 & -2 & & & 0.040 & \\
\hline microbial eukaryotes & - & - & - & - & - & - \\
\hline
\end{tabular}


Table 5. Species richness (average number of peaks) as determined by LH-PCR.

\begin{tabular}{|c|c|c|c|c|c|c|c|c|}
\hline Archaea & \multicolumn{2}{|c|}{ Vallgornera } & \multicolumn{2}{|c|}{ Drac Negre } & \multicolumn{2}{|c|}{ Drac Delícies } & \multicolumn{2}{|c|}{ Drac Martel } \\
\hline Depth $(m)$ & $\begin{array}{l}\text { Ave \# } \\
\text { peaks }\end{array}$ & $\begin{array}{l}\text { Std } \\
\text { Dev }\end{array}$ & $\begin{array}{l}\text { Ave \# } \\
\text { peaks }\end{array}$ & $\begin{array}{l}\text { Std } \\
\text { Dev }\end{array}$ & $\begin{array}{l}\text { Ave \# } \\
\text { peaks }\end{array}$ & $\begin{array}{l}\text { Std } \\
\text { Dev }\end{array}$ & $\begin{array}{l}\text { Ave \# } \\
\text { peaks }\end{array}$ & $\begin{array}{l}\text { Std } \\
\text { Dev }\end{array}$ \\
\hline 0 & 20.60 & 2.51 & 25.75 & 2.99 & 21.60 & 2.61 & 24.25 & 1.50 \\
\hline-1 & 19.40 & 2.88 & 28.00 & 4.53 & 21.20 & 2.28 & 19.25 & 3.86 \\
\hline-2 & 16.00 & 4.36 & 30.40 & 3.36 & 21.75 & 4.03 & 14.25 & 6.08 \\
\hline Bacteria & \multicolumn{2}{|c|}{ Vallgornera } & \multicolumn{2}{|c|}{ Drac Negre } & \multicolumn{2}{|c|}{ Drac Delícies } & \multicolumn{2}{|c|}{ Drac Martel } \\
\hline Depth (m) & $\begin{array}{l}\text { Ave \# } \\
\text { peaks }\end{array}$ & $\begin{array}{l}\text { Std } \\
\text { Dev }\end{array}$ & $\begin{array}{l}\text { Ave \# } \\
\text { peaks }\end{array}$ & $\begin{array}{l}\text { Std } \\
\text { Dev }\end{array}$ & $\begin{array}{l}\text { Ave \# } \\
\text { peaks }\end{array}$ & $\begin{array}{l}\text { Std } \\
\text { Dev }\end{array}$ & $\begin{array}{l}\text { Ave \# } \\
\text { peaks }\end{array}$ & $\begin{array}{l}\text { Std } \\
\text { Dev }\end{array}$ \\
\hline 0 & 15.60 & 2.41 & 1.00 & 0.82 & 3.00 & 0.00 & 16.25 & 2.87 \\
\hline-1 & 13.60 & 2.88 & 25.20 & 3.83 & 2.40 & 0.55 & 16.25 & 2.75 \\
\hline-2 & 15.40 & 1.34 & 23.60 & 0.55 & 1.25 & 1.26 & 17.25 & 2.50 \\
\hline Eukaryote & \multicolumn{2}{|c|}{ Vallgornera } & \multicolumn{2}{|c|}{ Drac Negre } & \multicolumn{2}{|c|}{ Drac Delícies } & \multicolumn{2}{|c|}{ Drac Martel } \\
\hline Depth $(m)$ & $\begin{array}{l}\text { Ave \# } \\
\text { peaks }\end{array}$ & $\begin{array}{l}\text { Std } \\
\text { Dev }\end{array}$ & $\begin{array}{l}\text { Ave \# } \\
\text { peaks }\end{array}$ & $\begin{array}{l}\text { Std } \\
\text { Dev }\end{array}$ & $\begin{array}{l}\text { Ave \# } \\
\text { peaks }\end{array}$ & $\begin{array}{l}\text { Std } \\
\text { Dev }\end{array}$ & $\begin{array}{l}\text { Ave \# } \\
\text { peaks }\end{array}$ & $\begin{array}{l}\text { Std } \\
\text { Dev }\end{array}$ \\
\hline 0 & 2.40 & 0.89 & 4.25 & 0.50 & 3.00 & 0.71 & 2.75 & 2.22 \\
\hline-1 & 5.20 & 3.11 & 5.20 & 2.39 & 3.40 & 1.14 & 3.75 & 0.50 \\
\hline-2 & 3.80 & 1.48 & 3.80 & 2.05 & 2.75 & 0.96 & 4.50 & 1.00 \\
\hline
\end{tabular}

manner as estimated total abundance. Even though Drac Martel showed no statistically significant differences of estimated total abundance between any depths for all domains, there was a statistically significant difference of species richness of Archaea between the surface and $2 \mathrm{~m}$. Vallgornera showed a statistically significant difference in estimated total abundance of Archaea and Bacteria between the surface and $2 \mathrm{~m}$ and a statistically significant difference of species richness of Archaea between the surface and $2 \mathrm{~m}$. Seymour et al. (2007) found that microbial populations can be stratified within anchialine sinkholes and that some populations are only found in specific zones determined by water chemistry. For example, they found that phytoplankton abundance was greatest within a layer with high ammonia concentrations and that bacterial abundance was greatest near a layer of hydrogen sulfide. In our study, no statistically significant differences of species richness of microbial eukaryotes were seen with depth at any site and there was only a statistically significant difference of estimated total abundance of microbial eukaryotes between the surface and $2 \mathrm{~m}$ at Drac Delícies. No difference in estimated total abundance and species richness could be due to the low values for microbial eukaryotes at all sites suggesting that microbial eukaryotes may not contribute to the biodiversity of these systems as much as Archaea and Bacteria although they may still play an important ecological role.

\section{Assessment of microbial communities}

Estimated total abundance and species richness do not tell the entire story. For example, the results of least significant difference post-hoc tests presented in Table 3 show that there are no significant differences in estimated total abundance or species richness between Vallgornera and Drac Martel for any domain even though there are clear differences in salinity, sulfate, and other chemical gradients between the two sites. Estimated total abundance (q-PCR) only estimates the size of the community while species richness (LH-PCR) only estimates the total number of different species in the community. Relative species abundance is the proportion of each species (e.g. LH-PCR peaks) present in each sample. Multidimensional scaling (MDS) plots allow a closer look at the communities by comparing both estimated total abundance and relative species abundance among samples as estimated absolute abundance (see Methods).

The MDS plot displaying estimated absolute abundance data of the microbial communities at all sites and depths is shown in Figure 4. It can be seen that the communities clearly separate into four distinct groups. Drac Martel appears to have a unique microbial community that is different from the other three sites. The Drac Martel samples from different depths grouped together, with a few outliers, suggesting a well-mixed water column. Conversely, the MDS plot suggests that at Drac Delícies, there is a biological gradient with depth because the surface samples are to the left of the Drac Delícies cluster, the $1 \mathrm{~m}$ samples are in the middle and the $2 \mathrm{~m}$ samples to the right. The $1 \mathrm{~m}$ and $2 \mathrm{~m}$ samples from Drac Negre are tightly clustered with the $1 \mathrm{~m}$ samples to the left and the $2 \mathrm{~m}$ samples to the right but the surface samples are to the far right and not in the cluster. The Vallgornera samples are cluster tightly together, with the $1 \mathrm{~m}$ and $2 \mathrm{~m}$ samples mostly together and the surface samples farther to the right. The grouping of Vallgornera samples includes samples from the surface of Drac Negre and samples from $2 \mathrm{~m}$ of Drac Delícies. This could mean that similar communities are found within varying distances from each other, approximately $100 \mathrm{~m}$ between Drac Negre and Drac Delícies, and $57 \mathrm{~km}$ between Vallgornera and Coves del Drac. This finding suggests that these two spatially separated systems are operating under similar ecological constraints. In a study of cenotes and anchialine caves in the Yucatan Peninsula of Mexico, Sanchez et al. (2002) found similar results in that similar phytoplankton communities were found in systems approximately eight $\mathrm{km}$ apart. They suggest that the similarities seen between sites are due to a shared freshwater source. Future studies incorporating the complex hydrological framework underlying the island of Mallorca and microbial species information could possibly determine more conclusive microbial linkages between cave systems.

The Drac Martel samples appear distinct from samples of other sites within the Drac system (Fig. 4) and may be a result of exogenous biota or increased nutrients brought in by human activities due to the development of the site as a tourist attraction. Ikner et al. (2007) found that the development of a cave in Arizona, USA for tourism led to an increase of organic carbon inputs to the areas most traveled, but also found that the placement of lights along the tourist path led to algal growth near the lights. They determined that Proteobacteria were the most abundant microbe on the tourist path whereas Firmicutes were the most abundant microbes in areas 
less impacted by tourism. While our study did not examine species information, our MDS plot suggests differences in microbial communities between the tourist and non-tourist areas within the pools in Drac and similarities between non-tourist areas of different cave systems.

The MDS plots of microbial communities at each site by depth (Fig. 4) indicate varying degrees of biological gradation. Drac Delícies showed more biological gradation with depth than any of the other three sites whereas Drac Martel appeared to have no biological gradation. This most likely has to do with the amount of perturbation of the water column in Drac Martel due to tourist traffic. This analysis suggests that the drivers of microbial community gradation varied from site to site, and could be due to differences in the amount of mixing between fresh and salt water from different sources, freshwater inputs at Drac Negre, and/or water column mixing due to boat traffic at Drac Martel.

\section{CONCLUSIONS}

This study documented distinct biogeochemical differences between each site and depth in sampled water columns from two caves. Some of the chemical gradients observed within the sampled caves can be explained by simple mixing of surface fresh water with Mediterranean-derived saltwater although data from Drac Negre indicates increased fresh groundwater input at that site. Not all chemical constituents followed a similar mixing pattern, indicating a complex hydrological model that needs further study. We found biological community differences with depth at all of the sites except for Drac Martel (Table 4). The biological gradients formed in Vallgornera, Drac Negre, and Drac Delicies are most likely due to the lack of water perturbation whereas the lack of biological gradients at Drac Martel is most likely due to mixing of the water by boat traffic.

Estimated total abundance data suggests that Archaea are the most prevalent component of the microbial communities in the sampled cave systems. Microbial eukaryotes represent an order of magnitude fewer microbial organisms than Archaea suggesting that nutrient limitations and/or other environmental factors may play a role in their low abundance. At Drac Negre, which was the only site with significant amounts of microbial eukaryote DNA, there appears to be an inverse relationship between the amount of microbial eukaryote DNA and prokaryote DNA with depth, suggesting predation of microbial prokaryotes by eukaryotes. Estimated total abundance data also suggests biological gradations at all sites with depth except for at Drac Martel. Within Drac, the different pools appear to support vastly different quantities of microbes. However, estimated total abundance data showed that there were no significant differences between Drac Martel and Vallgornera suggesting that these two sites may be operating under similar ecological constraints.

Relative species abundance data suggests that Archaea have the highest species richness within the sampled cave systems while microbial eukaryotes had the lowest species richness, similar to the estimated total abundance results. Drac Delícies showed far lower bacterial species richness than the other sites. The unique archaeal communities in Drac Negre and the unique bacterial communities in Drac Delicies

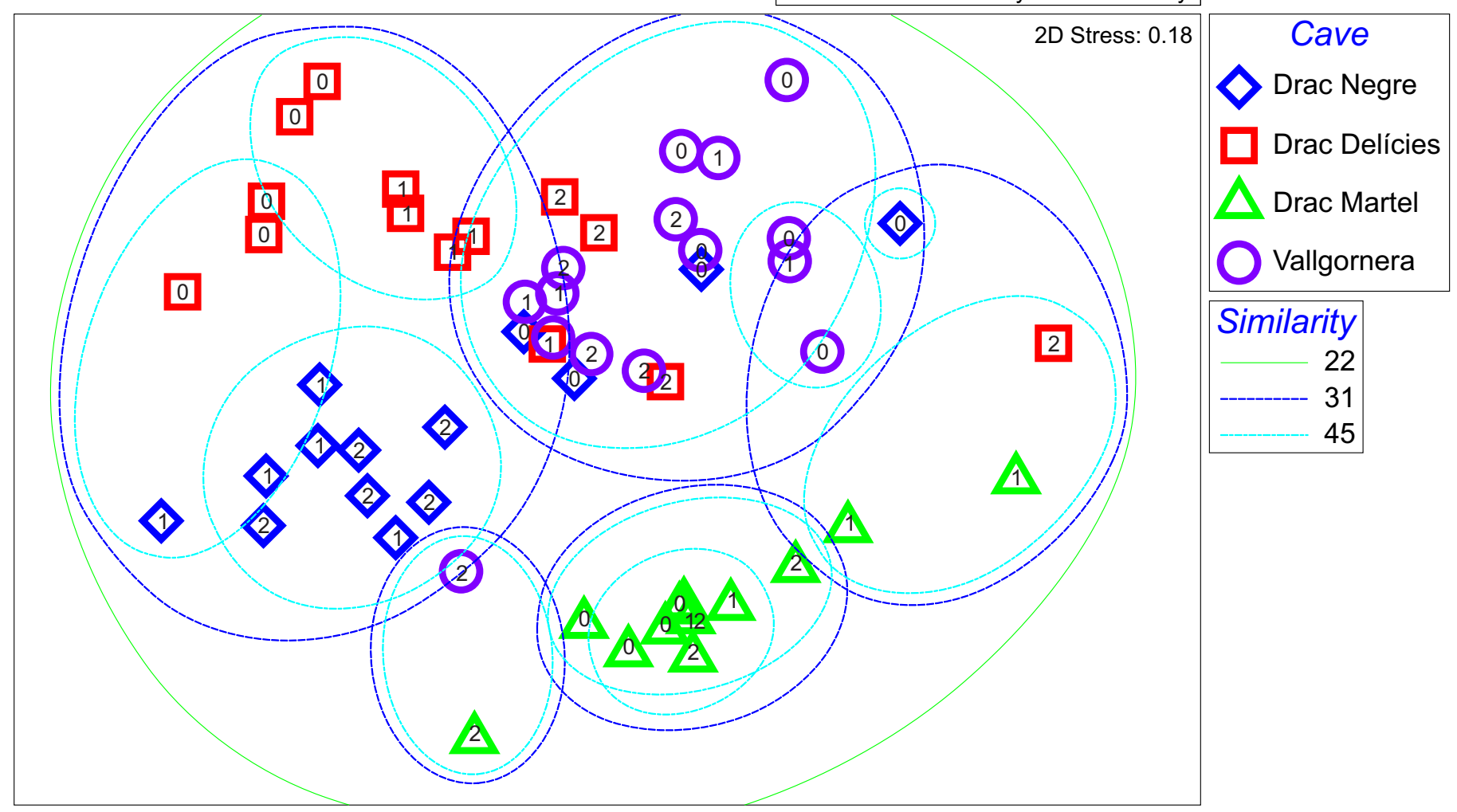

Fig. 4. Multidimensional scaling plot showing community structure distribution of all sites and depths. Symbols with the same shape, color, and number represent replicate samples. Numbers within each sample symbol refer to the depth at which the sample was taken in meters. Lines around the data points indicate the percent similarity between samples contained within the line. 
suggest a separation of biological communities into distinct niche habitats within the same cave system.

The estimated absolute abundance data suggests that there are distinct communities inhabiting different ecological niches that may be dependent on chemical gradients within the water column. Distinct differences in both water chemistry (Fig. 3) and microbial communities (Table 3 and Fig. 4) are seen between all three sites within Drac despite their close proximity to each other. Drac Negre had the highest estimated total abundance of microbial eukaryotes of all the sites and was significantly different compared to the other three sites. The differences seen in the microbial communities of Drac may be due to freshwater inputs at Drac Negre and/or the introduction of exogenous biota and/or increased nutrients brought in by tourists in Drac Martel.

Our findings suggest that Drac Negre and Vallgornera have biological gradients that are less developed than Drac Delicies, but more developed than Drac Martel, suggesting differences in hydrological patterns between the systems. The MDS plot of estimated absolute abundance data shows a high degree of similarity between Drac Delícies, Drac Negre, and Vallgornera even though Vallgornera is approximately $57 \mathrm{~km}$ to the southwest. This suggests there could be a biological connectivity between the spatially disconnected cave systems found on the island of Mallorca. Long-term studies incorporating more detailed species information and hydrological characteristics of the caves on the island of Mallorca are needed to determine the extent of connections between the spatially separated systems.

\section{ACKNOWLEDGEMENTS}

We thank the administration of Coves del Drac (Porto Cristo) who facilitated research in the cave. We also thank Antoni Merino, Emily Jackson, and Laura del Valle Villalonga for assisting with sample collection and field work.

\section{REFERENCES}

Baker G.C., Smith J.J., \& Cowan D.A., 2003 - Review and re-analysis of domain-specific $16 \mathrm{~S}$ primers. Journal of Microbiological Methods, 55 (3): 541-555.

http://dx.doi.org/10.1016/j.mimet.2003.08.009

Balaguer P., 2005 - Tipus $i$ evolucio de les costs rocoses de Mallorca. Unpublished Ph.D. Thesis, Universitat de les Illes Balears, Palma de Mallorca, 373 p.

Boop L.M., Onac B.P., Wynn J.G., Fornós J.J., Rodríguez-Homar M., Merino A., 2014 - Groundwater geochemistry observations in littoral caves of Mallorca (western Mediterranean): implications for deposition of phreatic overgrowths on speleothems. International Journal of Speleology 43 (2): 193-203. http://dx.doi.org/10.5038/1827-806X.43.2.7

Carey P.G., Sargent A.J., Taberner A.M., Ramon G. \& Moya G., 2001 - Ecology of cavernicolous ciliates from the anchialine lagoons of Mallorca. Hydrobiologia, 448: 193201. http://dx.doi.org/10.1023/A:1017509623778

Culver D.C., 1970 - Analysis of simple cave communities: Niche separation and species packing. Ecology, 51 (6): 949-958. http://dx.doi.org/10.2307/1933622
Curry M.D., Boston P.J., Spilde M.N., Baichtal J.F. \& Campbell A.R., 2009 - Cottonballs, a unique subaqeous moonmilk, and abundant subaerial moonmilk in Cataract Cave, Tongass National Forest, Alaska. International Journal of Speleology, 38 (2): 111-128.

http://dx.doi.org/10.5038/1827-806X.38.2.3

Ducklow H.W., Myers K.M.S., Erickson M., Ghiglione J-F. \& Murray A.E., 2011 - Response of a summertime Antarctic marine bacterial community to glucose and ammonium enrichment. Aquatic Microbial Ecology, 64: 205-220. http://dx.doi.org/10.3354/ame01519

Garman K.M., Rubelmann H., Karlen D.J., Wu T. \& Garey J.R., 2011 - Comparison of an inactive submarine spring with an active nearshore anchialine spring in Florida. Hydrobiologia, 677 (1): 65-87.

http://dx.doi.org/10.1007/s10750-011-0740-2

Garey J.R. \& Menning D.M., 2012 - The dynamics of community structure within a submarine coastal spring with an anchialine source. Natura Croatica, 21 (1): 43-46.

Gili J.M., Riera T. \& Zabala M., 1986 - Physical and biological gradients in a submarine cave on the Western Mediterranean coast (north-east Spain). Marine Biology, 90 (2): 291-297.

http://dx.doi.org/10.1007/BF00569141

Ginés A. \& Ginés J., 2007 - Eogenetic karst, glacioeustatic cave pools and anchialine environments on Mallorca Island: a discussion of coastal speleogenesis. International Journal of Speleology, 36 (2): 57-67. http://dx.doi.org/10.5038/1827-806X.36.2.1

Ginés A., Ginés J., Gómez-Pujol L., Onac B.P. \& Fornós, J.J. (Eds.), 2012 - Mallorca: A Mediterranean Benchmark for Quaternary Studies. Monografies de la Societat d'Historia de les Balears, 18, 220 p.

Ginzinger D.G., 2002 - Gene quantification using realtime quantitative PCR: An emerging technology hits the mainstream. Experimental Hematology, 30 (6): 503-512. http://dx.doi.org/10.1016/S0301-472X(02)00806-8

Giovannoni S.J., 1991 - The polymerase chain reaction. In: Stackenbrandt E. \& Goodfellow M. (Eds.) - Nucleic Acid Techniques in Bacterial Systematics. John Wiley \& Sons, Inc, New York, N.Y.: 177-203.

Ikner L.A., Toomey R.S., Nolan G., Neilson J.W., Pryor B.M. \& Maier R.M., 2007 - Culturable microbial diversity and the impact of tourism in Kartchner Caverns, Arizona. Microbial Ecology, 53: 30-42. http://dx.doi.org/10.1007/s00248-006-9135-8

Lane D.J., 1991 - 16S/23S rRNA sequencing. In: Stackenbrandt E. \& Goodfellow M. (Eds.) - Nucleic Acid Techniques in Bacterial Systematics. John Wiley \& Sons, Inc, New York, N.Y.: 115-175.

Léveillé R.J., Longstaffe F.J. \& Fyfe W.S., 2007 - An isotopic and geochemical study of carbonate-clay mineralization in basaltic caves: abiotic versus microbial processes. Geobiology, 5 (3): 235-249.

http://dx.doi.org/10.1111/j.1472-4669.2007.00109.x

Lloyd K.G., May M.K., Kevorkian R. \& Steen A.D., 2013 - Meta-analysis of quantification methods shows Archaea and bacteria to be similarly abundant in the subseafloor. Applied and Environmental Microbiology, 79 (24): 7790-7799.

http://dx.doi.org/10.1128/AEM.02090-13

Lovley D.R. \& Chapelle F.H., 1995 - Deep subsurface microbial processes. Reviews of Geophysics, 33 (3): 365-381. http://dx.doi.org/10.1029/95RG01305

Marzorati M., Wittebolle L., Boon N., Daffonchio D. \& Verstraete W., 2008 - How to get more out of molecular fingerprints: practical tools for microbial ecology. Environmental Microbiology, 10 (6): 1571-1581. http://dx.doi.org/10.1111/j.1462-2920.2008.01572.x 
Mutlu M.B., Martínez-García M., Santos F., Peña A., Guven K. \& Antón J., 2008 - Prokaryotic diversity in Tuz Lake, a hypersaline environment in Inland Turkey. FEMS Miccrobiology Ecology, 65 (3): 474-483. http://dx.doi.org/10.1111/j.1574-6941.2008.00510.x Olliver J., Yang S., Dörfer C., Welzl G., Kühn P., Scholten T., Wagner D. \& Schloter, M., 2014 - Bacterial community structure in soils of the Tibetan Plateau affected by discontinuous permafrost or seasonal freezing. Biology and Fertitility of Soils, 50 (3): 555-559. http://dx.doi.org/10.1007/s00374-013-0869-4

Por F.D., 2007 - Ophel: a groundwater biome based on chemoautotrophic resources. The global significance of the Ayyalon cave finds, Israel. Hydrobiologia, 592: 1-10. http://dx.doi.org/10.1007/s10750-007-0795-2

Robledo P.A. \& Duran J.J., 2010 - Evolución del turismo subterráneo en las Islas Baleares y su papel en el modelo turístico. In: Duran, J.J. and Carrasco, F. (Eds.), Cuevas: Patrimonio, Naturaleza, Cultura y Turismo: Madrid, Asociación de Cuevas Turísticas Españolas, p. 305-322.

Reysenbach A.-L. \& Pace N.R., 1995 - In: Robb, F.T., Place, A.R. (Eds.), Archaea: A Laboratory Manual Thermophiles. Cold Spring Harbour Laboratory Press, New York, pp. 101-107.

Sanchez M., Alcocer J., Escobar E. \& Lugo A., 2002 Phytoplankton of cenotes and anchialine caves along a distance gradient from the northeastern coast of Quintana Roo, Yucatan Peninsula. Hydrobiologia, 467: 79-89. http://dx.doi.org/10.1023/A:1014936714964

Seymour J.R., Humphreys W.F.\& Mitchell J.G., 2007 Stratification of the microbial community inhabiting an anchialine sinkhole. Aquatic Microbial Ecology, 50: 11-24. http://dx.doi.org/10.3354/ame01153

Sintes E., Martínez-Taberner A., Moyà G \& Ramon G., 2004 - Dissecting the microbial food web: structure and function in the absence of autotrophs. Aquatic Microbial Ecology, 37: 283-293.

http://dx.doi.org/10.3354/ame037283
Sogin M.L. \& Gunderson J.H., 1987 - Structural diversity of Eukaryotic Small Subunit Ribosomal RNAs - Evolutionary Implications. Annals of the New York Academy of Sciences, 503: 125-139. http://dx.doi.org/10.1111/j.1749-6632.1987.tb40603.x Sogin M.L., Morrison H.G., Huber J.A., Welch D.M., Huse S.M., Neal P.R., Arrieta J.M. \& Herndl G.J., 2006 - Microbial diversity in the deep sea and the underexplored "rare biosphere". Proceedings of the National Academy of Sciences of the United States of America, 103 (32): 12115-12120. http://dx.doi.org/10.1073/pnas.0605127103

Suzuki M., Rappé M.S. \& Giovannoni S.J., 1998 - Kinetic Bias in Estimates of Coastal Picoplankton Community Structure Obtained by Measurements of Small-Subunit rRNA Gene PCR Amplicon Length Heterogeneity. Applied and Environmental Microbiology, 64 (11): 4522-4529.

Torres-Talamante O., Alocer J., Beddows P.A., EscobarBriones E.G. \& Lugo A., 2011 - The key role of the chemolimnion in meromictic cenotes of the Yucatan Peninsula, Mexico. Hydrobiologia, 677 (1): 107-127. http://dx.doi.org/10.1007/s10750-011-0746-9

Venarsky M.P., Anderson F.E. \& Wilhelm F.H., 2009 Population genetic study of the U.S. federally listed Illinois cave amphipod, Gammarus acherondytes. Conservation Genetics, 10 (4): 915-921. http://dx.doi.org/10.1007/s 10592-008-9579-0

Ward J.V. \& Palmer M.A., 1994 - Distribution patterns of interstitial freshwater meiofauna over a range of spatial scales, with emphasis on alluvial river-aquifer systems. Hydrobiologia, 287 (1): 147-156. http://dx.doi.org/10.1007/BF00006903

Žic V., Truesdale V.W., Cuculić V. \& Cukrov N., 2011 Nutrient speciation and hydrography in two anchialine caves in Croatia: tools to understand iodine speciation. Hydrobiologia, 677: 129-148. http://dx.doi.org/10.1007/s10750-011-0686-4 